\title{
QUANDO ACUSAR É PUNIR: QUINQUAGÉSIMO ANIVERSÁRIO DO DIREITO CONVENCIONAL A SER BEM ACUSADO
}

\author{
WHEN ACCUSING STANDS FOR PUNISHMENT: \\ FIFTIETH ANNIVERSARY OF THE CONVENTIONAL RIGHT OF BEING PROPERLY ACCUSED
}

"Let the jury consider their verdict"

the King said, for about the twentieth time that day.

'No, no!' said the Queen. 'Sentence first-verdict afterward' 'Stuff and nonsense!' said Alice loudly. 'The idea of having the sentence first!'"

Bruno Hermes Leal

Juiz Federal Titular da Subseção Judiciária de TabatingalAM (TRF/1a Região)

Mestre em Direito (UFRGS)

brunoleal88@hotmail.com

\section{RESUMO}

Este artigo nasce do propósito de articular a fundamentalidade convencional do direito a ser bem acusado, qualificado como garantia pelo artigo 8.2 da quinquagenária Convenção Interamericana sobre Direitos Humanos, com o caráter autonomamente punitivo da pretensão acusatória desenvolvida à margem dos marcos normativos internacionais e nacionais. Para tanto, segmentou-se a dicotomia analítica do "acusar" e do "punir", em um primeiro momento (1), na investigação, de um lado, sobre os (1.1) marcos normativos internacionais e nacionais que conformam o direito a ser bem acusado, com especial ênfase ao Pacto de São José da Costa Rica e à Constituição Federal de 1988; de outro, sobre (1.2) as balizas mais concretas que delineiam o perfil dogmático do controle jurisdicional da pretensão acusatória no direito processual penal brasileiro. $\mathrm{Na}$ segunda parte (2), a narrativa adquire caracteres mais pragmáticos tendentes a desdobrar o potencial explicativo da efetiva punição implementada pelo Poder Judiciário, enfatizando (2.1) os superiores atributos epistemológicos do contraste entre as premissas teóricas da primeira parte com a análise de casos concretos, (2.2) destacando-se o exemplo da responsabilidade penal corriqueiramente imputada a gestores públicos à luz de parâmetros objetivos.

Palavras-chave: Processo penal. Acusação. Garantias. CADH. Gestores públicos.

CARROLL, L. Alice's adventures in wonderland, 2005, p. 87. 


\begin{abstract}
This paper came from the purpose of articulating the conventional fundamentality of the right of being properly accused, qualified as a guarantee by art. 8.2 of the Inter-American Convention on Human Rights, with the punitive character of the accusatory claim developed in disagreement with the international and national normative frameworks. For this purpose, the analytical dichotomy of "accusing" and "punishing" was first segmented (1) in the investigation, on the one hand, of the (1.1) international and national normative frameworks that make up the right of being properly accused, with special emphasis on the Pact of San José of Costa Rica and the Federal Constitution of 1988; on the other, on (1.2) the most concrete marks that outline the dogmatic profile of the judicial control of the accusatory pretension in Brazilian criminal procedural law. In the second part (2), the narrative acquires more pragmatic traits tending to unfold the explanatory potential of the effective punishment implemented by the Judiciary, emphasizing (2.1) the superior epistemological attributes of the contrast between the theoretical premises of the first part with the analysis of concrete cases, (2.2) highlighting the example of criminal liability that is commonly attributed to public managers according to an objective pattern.
\end{abstract}

Keywords: Criminal proceedings. Accusation. Guarantees. CADH. Public managers.

Data de submissão: 17/12/2018

Data de aceitação: 07/05/2019

\title{
SUMÁRIO
}

INTRODUÇÃO 1. ACUSAR 1.1 Direito convencional a ser bem acusado 1.2 Controle jurisdicional da pretensão acusatória 2. PUNIR 2.1 Relevância epistemológica da casuística forense 2.2 Responsabilidade penal objetiva de gestores públicos. CONSIDERAÇÓES FINAIS. 


\section{INTRODUÇÁO}

Em obra publicada em 2005, o jusfilosófo belga Michel Van de Kerchove envidou esforços intelectivos à demonstraçáo de que o julgamento penal, na contemporaneidade, pode assumir deslocada autonomia relativamente à aplicação da pena, desempenhando ele próprio, enquanto discurso e ato de linguagem, os caracteres aflitivo e infamante da pena ${ }^{2}$.

Inspirado na sugestiva obra daquele autor - intitulada: Quand dire, c'est punir ${ }^{3}$-, este ensaio pretende congregar consideraçóes teóricas e práticas a respeito do elo normativo entre as regras com que o direito processual penal brasileiro disciplina o controle jurisdicional da pretensão acusatória, de um lado, e a estatura dignitária que a Convenção Americana sobre Direitos Humanos (doravante $\mathrm{CADH}^{4}$ ) outorga aos acusados no processo penal.

Passando em revista a história do direito processual penal, inclusive sob a perspectiva comparatista, Kerchove revela a capilaridade da compreensáo segundo a qual o julgamento é discurso constitutivo, ao ponto de sua própria enunciação pública assumir relevância ímpar ${ }^{5}$, ao mesmo tempo em que propicia a arcaica existência de execuçóes penais que

$2 \quad$ Em uma das mais expressivas passagens da obra citada, Kerchove afirma: "Sans constituer la seule manifestation de leur unité, le prononcé du jugement semble être par excellence l'acte dans lequel se nouent ces deux dimension de la peine, sous une forme en quelque sorte épurée à l'extrême, où l'instrument de la souffrance et de l'infamie se réduit à un ensemble de paroles énoncées" (KERCHOVE, M. V. de. Quand dire, c'est punir. Essai sur le jugement pénal. Bruxelles: FUSL, 2005).

3 As referências bibliográficas a respeito da ascendência semiótica perfilhada por Michel Van de Kerchove (Quand dire, c'est punir. Essai sur le jugement pénal. Bruxelles: FUSL, 2005. pp. 09 et seq) são numerosíssimas, dentre as quais destaco, por sua pertinência, AUSTIN, J. L. Quand dire, c'est faire. Traduit par G. Lane. Paris: Seuil, 1970, pp. 151 et seq. O caráter performativo da linguagem jurídica, em geral, e da jurisdiçáo, em particular, pode ser aprofundado em LEGAULT, G. A. La structure performative du langage juridique. Montréal: PUM, 1977, pp. 465 et seq. A rigor, convém lembrar, a natureza constitutiva da jurisdição já se encontra, para o "escândalo" dos que lhe atribuem a paternidade do positivismo exegético, em KELSEN, H. Reine Rechtslehre. 2. Aufl. Wien: Österreichische Staatsdruckerei, 1992, p. 243: "Eine gerichtliche Entscheidung hat nicht, wie dies mitunter angenommen wird, einen blo $\beta$ deklaratorischen Charakter. Das Gericht hat nicht blo $\beta$ ein schon vorher fix und fertig geschaffenes , in seiner Erzeugung abgeschlossenes Recht zu finden und auszusprechen. Die Funktion des Gerichtes ist nicht bloße Rechts-,,Findung” oder Recht-,,Sprechung” in diesem deklaratorischen Sinne. Rechtsfindung liegt nur in der Feststellung der auf den konkreten Fall anzuwendenden generellen Norm. Und auch diese Feststellung hat keinen blo $\beta$ deklaratorischen, sondern einen konstitutiven Charakter" (grifei).

$4 \quad$ O Decreto n. ${ }^{\circ}$ 678/1992, subscrito pelo então Presidente da República Itamar Franco, promulgou a Convenção Americana sobre Direitos Humanos (Pacto de São José da Costa Rica), de 22 de novembro de 1969. Mais de uma década se passou até que o Decreto n. ${ }^{0}$ 4.463/2002 promulgasse a Declaração de Reconhecimento da Competência Obrigatória da Corte Interamericana de Direitos Humanos e até que o Supremo Tribunal Federal reconhecesse à Convenção o status jurídico supralegal, no paradigmático caso da prisão do depositário infiel, disso emanando a inaplicabilidade da legislação infraconstitucional com ele conflitante (RE 466343, Pleno, Rel. Min. Cezar Peluso, julgado em 03/12/2008). A teor do artigo 4º, VI, da Lei Complementar n. ${ }^{\circ}$ 80/1994, à Defensoria Pública compete representar aos sistemas internacionais de proteçáo dos direitos humanos, postulando perante seus órgãos, donde ser justo que também esta instituiçáo essencial à Justiça seja homenageada por ocasião da celebração dos cinquenta anos de celebração do Pacto.

$5 \quad$ KERCHOVE, M. V. de. Quand dire, c'est punir, 2005, p. 102. 
se antecipam ao julgamento ${ }^{6}$. Além da tortura e da prisão provisória, o autor belga, por força de sua expressiva significaçáo histórica, destaca as ordálias do direito barbárico ${ }^{7}$, as quais revelavam, na crudelidade irracional de seus métodos, "un système processuel qui vise à la pacification des conflits, non à la recherche de la vérité" ${ }^{8}$.

Se, de um lado, a concepçáo tradicional assinalava a precedência da acusaçáo ao julgamento, e deste à imposição de pena, a contemporaneidade demonstra o atual estágio de assincronia desorganizadora desta sucessividade temporal ${ }^{9}$, soberbamente estimulada, no mínimo, por dois fatores: "espetacularização do processo penal"10 e laxismo dogmático no controle jurisdicional da pretensáo acusatória. Observando a estreiteza dos

\footnotetext{
6 O tema, por certo, é riquíssimo em desdobramentos no atual cenário brasileiro, entre os quais me permito destacar, para ficar apenas com os mais rumorosos exemplos, (a) a intermitente manutenção do entendimento segundo o qual a pena privativa de liberdade pode ser executada antes do trânsito em julgado da condenaçáo, tida pela composição majoritária do Supremo Tribunal Federal como compatível com o art. 5º, LVII, da Constituição Federal (HC 157159 AgR, 1a Turma, Rel. Min. Luiz Fux, julgado em 24/08/2018; RHC 155553 AgR, 2a Turma, Rel. Min. Dias Toffoli, julgado em 25/05/2018); (b) e o não menos controverso "Acordo de Não-Persecução Penal", supostamente admitido pelo art. 18 da Resolução n. ${ }^{\circ}$ 181/2017 do Conselho Nacional do Ministério Público. Esses assuntos, todavia, não serão abordados neste limitado espaço, seja pelo rigor que exige a ciência, seja pela paciência que exijo do leitor.

KERCHOVE, M. V. de. Quand dire, c'est punir, 2005, pp. 90 et seq. Para referências arqueológicas às ordálias, confiram-se: MITTERMAYER, C. J. A. Tratado da prova em matéria criminal. Traduzido da versão francesa por Araújo Filgueira Junior. Rio de Janeiro: Eduardo \& Henrique Laemmert, 1879. p. 10 et seq; ALMEIDA JÚNIOR, J. M. de. O processo criminal brasileiro. Rio de Janeiro: Baptista de Souza, 1920, pp. 52 et seq. A respeito da continuidade dos tormentos durante o Principado romano, confira-se MOMMSEN, T. Derecho penal romano. Traducido por P. Dorado. Bogotá: Temis, 1976, pp. 262 et seq. Excelente resenha histórica, na doutrina colombiana, se pode encontrar em ECHANDÍA, H. D. Teoría general de la prueba judicial. Bogotá: Temis, 2017, pp. 51 et seq.

$8 \quad$ JACOB, R. Jugement des hommes et jugement de Dieu à l'aube du Moyen Âge. In: Le juge et le jugement dans les traditions juridiques européennes. Études d'histoire comparée. Paris: LGDJ, 1996, p. 51.

9 Os desacoplamentos cronológicos do fenômeno jurídico foram amplamente abordados por François Ost à luz do quadrilátero da retemporalisation, através da memória (que liga o passado), do perdão (que desliga o passado), da promessa (que liga o futuro) e o questionamento (que desliga o futuro) (OST, François. Le temps du droit. Paris: Odile Jacob, 1999, pp. 33 et seq).
}

10 Tomo a expressão de empréstimo a Rubens Casara, denunciante do que entende ser a dicotomia entre o "processo penal democrático" (instrumento de racionalização do poder penal em que a preocupaçáo é com a reconstrução eticamente possível do fato atribuído ao réu) e o "processo penal do espetáculo", em que "o desejo de democracia é substituído pelo 'desejo de audiência" e "o que ocorre é o primado do enredo pelo fato", no qual "todos querem exercer bons papéis na trama” (CASARA, R. Processo penal do espetáculo. In: PRADO, G.; CHOUKR, A. C. F.; JAPIASSÚ, C. E. Processo penal e garantias. Estudos em homenagem ao professor Fauzi Hassan Choukr. Florianópolis: Empório do Direito, 2016, pp. $497-500$ passim). Em sentido semelhante, GOMES, M. A. Mídia e sistema penal. As distorções da criminalização nos meios de comunicação. Rio de Janeiro: Revan, 2015, passim. O tema, de fato, não é novidadeiro. Na literatura francesa, confira-se a densa investigação conduzida no décimo segundo capítulo ("la délocalisation de la scène judiciaire dans les médias”) de GARAPON, A. Bien juger. Essai sur le rituel judiciaire. Paris: Odile Jacob, 2001, pp. 267 et seq. Relevantes, também, as relaçóes entre "le magistrat et le quatrième pouvoir", abordadas por TRUCHE, P. Juger, être jugé. Le magistrat face aux autres et à lui-même. Paris: Fayard, 2001, pp. 86 et seq. No cenário italiano, o eminente penalista Giovanni Fiandaca critica parcela dos juízes italianos relativamente ao "atteggiamento ideologico della magistratura penale", demonstrado pela assunção voluntária do heterodoxo papel de "interprete della buona politica e guida morale della vita collettiva" (FIANDACA, G. Tra legge e giudice. In: Prima lezione di diritto penale. Bari: Laterza, 2017, p. 135), do que deriva, não raro, deliberada exposição midiática dos rumorosos processos sob seus cuidados. Merece menção, de igual sorte, a fabulosa monografia de Ennio Amodio, ao dissertar sobre "le distorsioni della giustizia mediatica", afirmando náo compreender "perché la giustizia mediatica, che ha la forza di denigrare l'imputato o il giudice, non sai in grado di turbare il processo sotto il profilo della corretta formazione del convincimiento giudiziale" (AMODIO, E. Estetica della giustizia penale. Milano: Giuffrè, 2016, p. 139). 
limites deste ensaio, concentrarei minha atenção exclusivamente sobre o segundo deles.

Embora a expressão possua raízes históricas por demais extensas para que sejam aqui abordadas ${ }^{11}$, emprego "laxismo", em apertada síntese, como signo expressivo do fenômeno segundo o qual, por diversificados fatores causais (volume de processos, recorrente superficialidade com que debatidas as teses defensivas na resposta à acusação, etc.), o magistrado não aprofunda o escrutínio jurisdicional da denúncia e profere decisóes procrastinatórias da minudente análise dos fatos em cotejo com as normas invocadas pela denúncia.

Em manifesta rota de colisão com a banalidade intrínseca a essa prática, aligeirado levantamento bibliográfico revela que são muitos os pensadores (juristas ou não) a salientarem o caráter autonomamente punitivo da simples acusaçáo, independentemente de qualquer manifestação judicial condenatória, quando descolada da pormenorizada análise das balizas normativas que conformam seu exercício.

No séc. XVIII, o Barão de Montesquieu, Charles-Louis de Secondat, já dizia que a maior parte da pena é a infâmia de sofrê-la, de sorte que a desgraça é um equivalente da pena e as formalidades mesmas dos julgamentos são puniçôes ${ }^{12}$. Quase dois séculos depois, em célebre lição, Francesco Carnelutti, invocando a autoridade de Santo Agostinho, afirmava: abolidos que estejam os suplícios corporais das modernas legislaçôes, "il semplice inizio e tanto più lo svolgimento del processo penale cagionano sofferenze" ${ }^{\prime 3}$, vale dizer, o processo mesmo é uma pena. A exemplo do que sucedia com os antigos cristáos, prossegue o autor, o homem sobre o qual pesa a suspeita de um delito é entregue ad bestias - a fera indomável e insaciável, no caso, é a multidão ${ }^{14}$.

Michel Foucault dirá sobre a sobrevivência de um fond suppliciant do fenômeno punitivo, mesmo após a superação histórica das práticas atentatórias à integridade corporal do apenado, alcançando-se o estágio da penalité de l'incorporel ${ }^{15}$ ou, na dicção de Kerchove, penalité de l'immatériel, seja mediante o recurso à supervisão eletrônica da liberdade, seja por intermédio da constrição patrimonial de apenados e familiares antes mesmo da existência de condenação ${ }^{16}$.

11 A genealogia da expressão "laxismo" remonta às controvérsias teológicas da casuística do séc. XVII com a doutrina da Igreja Católica, surgidas do advento de doutrinas morais mais indolentes ou "benignistas" com os novos hábitos da nobreza europeia. Após anos de disceptação capitaneada pelos jansenistas, as doutrinas laxistas foram condenadas pelo Papa Inocêncio X em 1679 (por todos, confira-se DENZINGER, H. Compêndio dos símbolos, definiçóes e declaraçóes de fé e moral. São Paulo: Loyola, 2015, p. 491, n. ${ }^{\circ}$ 2021). No Brasil, sua introdução na esfera jurídica se deu, até onde se pôde apurar, através da fina lavra do Desembargador Ricardo Dip, segundo o qual o "laxismo penal" designaria, em apertada síntese, fenômeno de "benevolência" da jurisdição criminal ao arrepio das disposições legais e/ou do acervo probatório (DIP, R.; JUNIOR, V. C. Crime e castigo. Campinas: Millennium, 2001, p. 16).

12 MONTESQUIEU, C.-L. S., B. de la B. et de. L'ésprit des lois, 1845, p. 66.

13 CARNELUTTI, F. Principi del processo penale. Napoli: Morano, 1960, p. 55. A referência parece fazer alusão ao Livro XIX da "Cidade de Deus", em cujo item VI o "Doctor Gratiae" exclama: "Que direi dessa tortura mesma que cada um sofre por sua própria causa?” (AUGUSTIN. La cité de Dieu. Traduit du latin par L. Moreau. Paris: Jacques Lecoffre, 1851, p. 215. Tome III - tradução livre).

14 CARNELUTTI, F. Las miserias del proceso penal,1959, pp. 75-76.

15 FOUCAULT, M. Surveiller et punir, 1975, p. 21.

16 KERCHOVE, M. V. de. Quand dire, c'est punir, 2005, pp. 223 et seq. 
Em recentíssima publicação, o professor da Università di Roma "La Sapienza", Giorgio Spangher, sublinhou que o processo penal é um instrumento através do qual a força estatal se exprime de maneira incisiva, náo apenas do ponto de vista da restriçáa (provisória ou definitiva) da liberdade, gozando, ao revés, de implicaçóes ainda mais amplas (econômicas, sociais, familiares, etc.) ${ }^{17}$. Daí poder dizer-se, ainda com o mestre italiano, que o açodamento das prisóes provisórias, por exemplo, enseja "vítimas processuais" 18 .

Nessa linha de intelecção, este artigo segmenta a dicotomia analítica do "acusar" e do "punir", em um primeiro momento (1), na investigação sobre (1.1) os marcos normativos internacionais e nacionais que conformam o direito a ser bem acusado, com especial ênfase ao Pacto de Sáo José da Costa Rica e à Constituiçáo Federal de 1988, de um lado; de outro, sobre (1.2) as balizas normativas mais concretas que delineiam o perfil dogmático do controle jurisdicional da pretensão acusatória no direito processual penal brasileiro. Em um segundo momento (2), a narrativa adquire caracteres mais pragmáticos tendentes a desdobrar o potencial explicativo da efetiva punição implementada pelo Poder Judiciário, enfatizando (2.1) os superiores atributos epistemológicos do contraste entre as premissas teóricas da primeira parte com a análise de casos concretos, (2.2) destacando-se, em seguida, o exemplo da responsabilidade penal objetiva corriqueiramente imputada a gestores públicos.

\section{ACUSAR}

\subsection{Direito convencional a ser bem acusado}

Ao caráter excessivamente difuso da expressão adotada (ser bem acusado) pretendo agregar, neste subcapítulo, a concretude normativa oriunda das garantias previstas, em geral, na CADH e, no particular, na Constituição Federal de 1988, sem prejuízo de que essa experiência regional seja iluminada pelos avanços conceituais granjeados sob a égide da Convenção Europeia de Direitos Humanos.

\footnotetext{
SPANGHER, G. Ragionamenti sul processo penale, 2018, p. 23.

18 SPANGHER, G. La "vittima del processo" per ingiusta e illegale detenzione. In: SPANGHER, G. La vittima del processo penale. Torino: Giappichelli, 2017, pp. 181 et seq. Os limites deste artigo não comportam maior exploração do tema, tampouco das razóes que justificam minha adesão meramente parcial à validade jurídica e filosófica desta afirmação. Não posso deixar de anotar - máxime no cenário brasileiro dos últimos decêndios, quando as consequências pragmáticas de diversificadas propostas teóricas, associadas ao lobby de organizações não-governamentais, inocularam na percepção pública verdadeiro repúdio à tutela dos direitos humanos na seara processual -, todavia, minha contrariedade às posiçóes segundo as quais o criminoso náo passa de vítima da sociedade e que o processo penal, esvaziado de sua teleologia impositiva da pena, deve claudicar ao redor de uma miscelânea circular de direitos defensivos tendentes à nulidade do procedimento. Para um breve panorama dessa crítica, entre tantos outros, o texto de FISCHER, D. O que é garantismo (penal) integral? In: CALABRICH, B.; FISCHER, D.; PELELLA, E. (Orgs.). Garantismo penal integral. Porto Alegre: Verbo Jurídico, 2017, pp. 59 et seq. Para uma tentativa de visão metacrítica dessa postura, KHALED JR., S. Garantismo à la carte: integral, desnatado ou semi-desnatado? In: Justiça social e sistema penal. Rio de Janeiro: Lumen Juris, 2016, pp. 129 et seq.
} 
E, ao fazê-lo, principio por anotar que a arqueologia civilizatória do processo penal indica, como ensinam os clássicos, que o Ministério Público exsurge como órgáo técnico - relegando ao passado as demandas iniciadas por particulares, à luz de ódios e princípios reprovados nos tribunais - destinado ao altíssimo propósito de evitar a impunidade e expelir das Cortes as paixóes pelas quais se orientam as vinganças privadas ${ }^{19}$.

A despeito das críticas dirigidas à "quadratura do círculo" em que consiste a (im)parcialidade do Ministério Público ${ }^{20}$, a essa profissionalização do órgão acusador corresponde, no plano dogmático, a insurgência do acusado como sujeito da relação processual penal, de cuja fisionomia conceitual se extrai não só o direito fundamental à defesa, como também igualdade expressa em direito ao contraditório ${ }^{21}$.

Hodiernamente, portanto, é pacífica a premissa de que o acusado é sujeito integrante da relação processual, titularizando, por força dessa especial qualidade, direitos ativos de intervenção (eleger defensor de sua confiança, formular requerimentos probatórios, excepcionar o magistrado, etc.) e direitos passivos de intervenção (ter sua dignidade respeitada na execuçáo de medidas restritivas da liberdade, náo ser obrigado a produzir prova contra si mesmo, etc.) $)^{22}$.

Deixam-no ver não apenas o presente momento do constitucionalismo brasileiro, mas também os documentos internacionais subscritos pela República Federativa do Brasil. Em relação àquele, permito-me ilustrar com o generoso arrolamento de garantias processuais penais extraíveis do texto da Constituição Federal de 1988 - dos quais destaco, para nossos fins, a cláusula assecuratória do contraditório e da ampla defesa inscrita no art. 5, LIV, CRFB/88, segundo a qual ninguém será privado da liberdade ou de seus bens sem o devido processo legal -, objeto de extensa produçáo doutrinária, ao ponto de, modernamente, poder-se afirmar que "o direito processual penal é [...] verdadeiro direito constitucional aplicado" 23 .

Com efeito, a processualística brasileira dos últimos trinta anos - sejam obras de maior es-

\footnotetext{
19 ALMEIDA, J. C. M. de. Processo penal, 1975, p. 217.

20 Refiro-me à célebre expressão de Francesco Carnelutti, segundo o qual "Se c’è una figura ambigua nel processo, civile e penale, è il pubblico ministero. Quando cominciai a occuparmene, nei primi tentativi di sistemazione del diritto processuale, la sua ambiguità $\mathrm{mi}$ ha colpito a tal segno da farmi venire in mente la quadratura del circolo: non è come quadrare un circolo costruire una parte imparziale?" (CARNELUTTI, F. Mettere il pubblico ministero al suo posto. In: Rivista di diritto processuale. Padova: CEDAM, 1953, p. 257). Vincenzo Manzini, realçando as diferenças com o processo civil, afirmava que o processo penal não conhece partes em sentido substancial, sendo que o acusador assume essa condição no âmbito puramente formal, isto é, perante o processo (MANZINI, V. Trattato di diritto processuale penale. Torino: UTET, 1952, p. 75). Na doutrina brasileira, confiram-se as lúcidas ponderaçóes de TORNAGHI, H. Instituiçóes de processo penal. Sáo Paulo: Saraiva, 1977, p. 413. Mais recentemente, um dos textos que mais bem desenvolveu a metáfora, exigindo também do Poder Judiciário determinadas limitaçóes garantísticas, é da lavra de COUTINHO, J. N. de M. Mettere il pubblico ministero al suo posto - ed anche il Giudice. In: CASARA, R.; LIMA, J. C. de (coords.). Temas para uma perspectiva crítica do direito: homenagem ao professor Geraldo Prado. Rio de Janeiro: Lumen Júris, 2010, pp. 509 et seq.
}

$21 \quad$ ROXIN, C. Derecho procesal penal, 2000, pp. 123 et seq.

22 ROXIN, C. Derecho procesal penal, 2000, pp. 123 et seq.

23 DIAS, J. de F. Direito processual penal, 2004, p. 74. 
pectro temático ${ }^{24}$, sejam monografias concentradas sobre um tópico determinado ${ }^{25}-$ tem convergido ao comum entendimento, sem embargo de episódicas disceptaçóes hermenêuticas que pouco alteram a extensão da aderência ao texto magno, de que a legislação processual penal deve ser interpretada à luz das normas constitucionais.

Sensibiliza-me, deveras, a orientaçáo amplamente dominante no contexto brasileiro, espelhada em diversificados acórdãos da Suprema Corte, segundo a qual o postulado do devido processo legal outorga a todo cidadáo o "direito a náo ser acusado por denúncia inepta", ao mesmo tempo em que proscreve o "abuso do poder de denúncia" 26. $\mathrm{Na}$ dicção do eminente Des. Fed. Néviton Guedes, em obra monográfica, nossa ordem jurídico-constitucional erige induvidoso "direito fundamental a uma acusação justa, o que implica uma acusaçáo precisa quanto à narração dos fatos, coerente quanto a sua conclusão (pedido) e, além de tudo, juridicamente fundamentada" 27.

Essa prerrogativa processual de extraçáo constitucional respeita, sobretudo, ao grave atentado ao status dignitatis do acusado promovido pela existência mesma de um processo penal, cuja estrutura dogmática deve absorver, em obséquio ao sobreprincípio da dignidade da pessoa humana (art. 1º, III, CRFB/88), os postulados da fragmentariedade e da subsidiariedade do direito penal material, em ordem a relativizar, mediante circunstanciada análise do caso concreto, a obrigatoriedade da ação penal ${ }^{28}$.

O alcance verdadeiramente global dessa premissa traduz-se em expressivos diplomas internacionais que se dedicaram ao tema. De um lado, o art. 6o-3 da Convençáo Europeia de Direitos Humanos dispóe que o acusado tem, entre outros direitos mínimos, os seguintes: (a) ser informado no mais curto prazo, em língua que entenda e de forma

\footnotetext{
$\overline{24}$ Refiro-me às obras cuja latitude temática engloba, ou a isso de propõe, todos os institutos do processo penal brasileiro, a exemplo dos manuais e tratados. Confiram-se, entre outros, LOPES JR., A. Direito processual penal. São Paulo: Saraiva, 2017, pp. 58-110 passim; BRITO, A. C. de; FABRETTI, H. B.; LIMA, M. A. F. Processo penal brasileiro. São Paulo: Atlas, 2015, pp. 13 et seq; CARVALHO, L. G. G. C. Processo penal e constituiçáo. São Paulo: Saraiva, 2014, pp. 36 et seq; além da extraordinária monografia de GIACOMOLLI, N. J. O devido processo penal. São Paulo: Atlas, 2016, máxime a partir da página 87.

25 Neste segmento, interessantíssimos desdobramentos possui a releitura constitucional do vetusto Decreto-Lei n.o 3.689/1941. Cito, exemplificativamente, quanto à competência jurisdicional, BADARÓ, G. H. Juiz natural no processo penal. São Paulo: RT, 2014, pp. 103 et seq; quanto à fase pré-processual, LOPES JR., A.; GLOECKNER, R. J. Investigaçáo preliminar no processo penal. São Paulo: Saraiva, 2014, pp. 29 et seq; quanto ao nemo tenetur se detegere; QUEIJO, M. E. O direito de náo produzir prova contra si mesmo. Sáo Paulo: Saraiva, 2012, pp. 69 et seq; quanto à fundamentalidade da presunção de inocência, MORAES, M. Z. de. Presunçáo de inocência no processo penal brasileiro. Rio de Janeiro: Lumen Juris, 2010, pp. 173 et seq; quanto à prisão em flagrante, MORAES, R. F. Prisáo em flagrante constitucional. Salvador: Juspodivm, 2018, pp. 67-138 passim; quanto às medidas cautelares, SANGUINÉ, O. Prisáo cautelar. Medidas alternativas e direitos fundamentais. Rio de Janeiro: Forense, 2014, pp. 45 et seq; quanto ao regime das nulidades, GLOECKNER, R. J. Nulidades no processo penal. São Paulo: Saraiva, 2017; quanto ao processo de execução penal, ROIG, R. D. E. Execuçáo penal. Teoria crítica. Sáo Paulo: Saraiva, 2017, pp. 31 et seq.

26 HC 84580/SP, 2a Turma, Rel. Celso de Mello, julgado em 25/08/2009.

27 GUEDES, N. O princípio da congruência na ação civil pública de improbidade administrativa. In: MARQUES, M. C. (coord.). Improbidade administrativa. Temas atuais e controvertidos. Rio de Janeiro: Forense, 2016, p. 294. Grifei.
}

28 CARvalHO, L. G. G. C. de. Processo penal e constituiçáo. São Paulo: Saraiva, 2014, p. 64. 
minuciosa, da natureza e da causa da acusação contra ele formulada; b) dispor do tempo e dos meios necessários para a preparaçáo da sua defesa ${ }^{29}$.

A doutrina internacional tem enfatizado que o influxo da Convenção sobre as legislações penais dos Estados-membros nada mais significa que a fixação de um standard mínimo ao tratamento processual dos acusados, valendo notar, a propósito dos direitos de defesa durante a fase preparatória do processo penal que, a "lógica protetora europeia" assume tríplice dimensão: (a) lógica evolutiva, a sugerir a exegese da Convenção a partir dos precedentes da Comissão e da Corte; (b) lógica combinatória, a reclamar a interpretação sistemática (imbricada) dos artigos da Convenção; (c) lógica graduada, a sinalizar o necessário escalonamento da tutela (quanto mais frágil se é, mais bem e mais rapidamente se deve estar protegido), em progressiva intensidade a partir da qualidade de suspeito até a qualidade de réu preso ${ }^{30}$.

Respeitante ao instrumento que inspirou este ensaio, destaco que o art. 8.2 da Convençáo Interamericana sobre Direitos Humanos, ao dispor sobre as garantias judiciais, estabelece que toda pessoa acusada de delito tem direito a que se presuma sua inocência enquanto não se comprove legalmente sua culpa. Entre as garantias mínimas arroladas neste dispositivo, duas merecem destaque aos nossos propósitos: (b) comunicaçáo prévia e pormenorizada ao acusado da acusaçáo formulada; e a (c) concessão ao acusado do tempo e dos meios adequados para a preparação de sua defesa.

A doutrina colombiana, por exemplo, tem imputado à eficácia expansiva da CADH a configuraçáo do "fenómeno de 'interamericanización' del derecho procesal penal", já que:

$29 \quad$ A minudente análise das virtualidades e lacunas dessa sistemática pode ser encontrada em AMBOS, K. Principios del proceso penal europeo. Análisis de la Convención Europea de Derechos Humanos. Traducido por Ana Beltrán e Guillermo Orce. Bogotá: Universidad Externado de Colombia, 2005, pp. 72 et seq. Lado outro, em sentido mais amplo, para uma extraordinária aproximação entre os fundamentos da jurisdição penal internacional e a dolorosa arqueologia histórica dos direitos fundamentais de matriz onusiana, a inspiradora obra de GARAPON, A. Des crimes qu'on ne peut ni punir, ni pardonner. Pour une justice internationale. Paris: Odile Jacob, 2002, pp. 161-260 passim.

$30 \quad$ Vejam-se as didáticas consideraçôes da professora da Université Robert Schuman (Strasbourg III), KOERING-JOULIN, R. A fase preparatória do processo penal: grandes linhas da jurisprudência europeia. In: DELMAS-MARTY, M. (org.). Processo penal e direitos do homem. Traduzido por Fernando de Freitas Franco. Barueri: Manole, 2004, pp. 19 et seq. A respeito da controvérsia entre a vinculaçáo dos juízes nacionais às decisóes da Corte de Estrasburgo e a "dottrina del margine di apprezzamento nazionale", veja-se o elucidativo debate de Paolo Ferrua e Giulio Ubertis, documentado em UBERTIS, G. Ancora sull'efficacia della giurisprudenza di Strasburgo. In: Argomenti di procedura penale IV. Milano: Giuffrè, 2016, pp. 115 et seq. Sobre as implicaçôes profundamente democráticas desveladas pelo "obbligo di conformarsi in via interpretativa al diritto UE", confira-se o sugestivo artigo de SALCUNI, G. L'interpretazione conforme al diritto europeo e la legittimazione democratica del giudice. In: MANNA, A. (org.). Il problema dell'interpretazione nella giustizia penale. Pisa: PUP, 2016, pp. 177 et seq. Sob outra perspectiva, evocando o caráter labiríntico emergente "di una trama normativa sempre più poliedrica, complessa ed articolata", o trabalho de MANES, V. Il giudice nel labirinto. Profili delle intersezioni tra diritto penale e fonti sovranazionali. Roma: Diké Giuridica Editrice, 2012, pp. 43 et seq. Sobre o famigerado "caso Taricco II", em que a Corte de Estrasburgo determinou, em apertada síntese, que os juízes "desaplicassem" o direito penal e processual penal de seus países em matéria de prescrição relativamente a delitos fiscais envolvendo o imposto de valor agregado (IVA), cujas repercussóes dizem respeito à integralidade da União Europeia, a abalizada opinião de KOSTORIS, R. La Corte costituzionale e il caso Taricco, tra tutela dei 'controlimiti' e scontro tra paradigmi. In: BERNARDI, A.; CUPELLI, C. (orgs.). Il caso Taricco e il dialogo tra le Corti. Lordinanza 24/2017 della Corte costituzionale. Napoli: Jovene, 2017, pp. 175 et seq. 
"la jurisprudencia de la Corte Interamericana de Derecho Huma nos será un parámetro para la correcta observancia del Pacto de San José (y los restantes instrumentos), lo cual significa que las autoridades colombianas están en la obligación de respetar las garantias judiciales y las normas relativas a la protección de la libertad y los otros derechos humanos, en las condiciones que indique la Corte Interamericana" ${ }^{31}$.

A necessária releitura da legislaçáo processual penal à luz das disposiçóes da CADH, segundo a interpretação que lhe confere a jurisprudência da Corte Interamericana, pode ser observada não apenas em Colômbia (onde a Ley n. ${ }^{\circ} 288$ reconheceu a obrigação do Estado colombiano de adotar as medidas legislativas, judiciárias e executivas necessárias para dar cumprimento às decisóes da Corte Interamericana), mas também no México (com explícita referência constitucional à $\mathrm{CADH}$ ) e na Argentina ${ }^{32}$.

Considerada a diretriz exegética fornecida pelo Supremo Tribunal Federal relativamente à hierarquia supralegal da $\mathrm{CADH}$, do caráter necessariamente pormenorizado da acusaçáo, de um lado, e da necessária concessão dos meios adequados para o exercício da defesa, de outro, parece lícito derivar, como faz Nereu Giacomolli, a exigência de que:

"além de apontar o autor, descrever o fato, com todas as suas circunstâncias, e fazer a devida adequaçáo jurídica, a completude imputacional exige enunciação dos meios, seu direcionamento espacial e temporal. Isso tudo com densidade concreta e não genérica, pois não há como haver defesa efetiva contra enunciaçóes etéreas" ${ }^{\text {"33 }}$.

$\mathrm{Na}$ jurisdição infraconstitucional brasileira, por exemplo, o Superior Tribunal de Justiça teve o ensejo de, invocando o art. 80-2 da CADH, assentar que a:

"denúncia genérica caracteriza-se pela imputação de vários fatos típicos, ge-
nericamente, a integrantes da pessoa jurídica, sem delimitar, minimamente,
qual dos denunciados teria agido de tal ou qual maneira. Patente, pois, que a
criptoimputaçáo da denúncia genérica vulnera os princípios constitucionais
da ampla defesa e do contraditório, bem como a norma extraída do art. $8^{\circ}$,
2, "b" e "c", da Convenção Americana de Direitos Humanos e do art. 41 do
CPP, haja vista a indevida obstaculização do direito conferido ao acusado de

31 CUÉlLAR, J. B.; LYNETT, E. M. El proceso penal. Fundamentos constitucionales y teoría general. Bogotá: Universidad Externado de Colombia, 2013, pp. 152-155 passim. Em sentido semelhante, com referências à jurisprudência da Corte Interamericana, confira-se LUGO, C. F. S. Los derechos del imputado en las audiencias preliminares. La jurisprudencia nacional y de las cortes internacionales. In: El proceso penal acusatório colombiano. Bogotá: EJAM, 2006, pp. 53 et seq.

32 As referências do Direito Comparado, tirei-as todas da resenha elaborada por: DEU, T. A. Sistemas procesales penales. La justicia penal en Europa y América. Madrid: Marcial Pons, 2012, pp. 263 et seq. À página 280 desta obra, aliás, consta didática tabela comparativa entre os sistemas de garantias penais estabelecidos pela CADH, CEDH (Convenção Europeia de Direitos Humanos), PIDCP (Pacto Internacional de Direitos Civis e Políticos) e CDFUE (Convenção de Direitos Fundamentais da União Europeia). Noutra obra, a mesma autora voltou ao tema: DEU, Teresa Armenta. Estudios de justicia penal. Madrid: Marcial Pons, 2014, pp. 389 et seq.

33 GIACOMOLLI, N. J. O devido processo penal, 2016, p. 162. 
preparar dignamente sua defesa" 34 .

Delineada a projeção convencional do direito a ser bem acusado, convém que a primeira parte deste artigo seja complementada com a exposição das balizas mais concretas que delineiam o perfil dogmático do controle jurisdicional da pretensão acusatória no direito processual penal brasileiro, do qual passo a tratar.

\subsection{Controle jurisdicional da pretensão acusatória}

Retomando a linha argumentativa que expus na introduçáo e as premissas hermenêuticas às quais dediquei o tópico anterior, se a acusação carrega hoje significado autonomamente punitivo (desgarrado, portanto, da condenação e da aplicação da pena), impende que sejam satisfeitos requisitos cuja enumeração o ordenamento constitucional outorga à legislação processual penal ${ }^{35}$.

Com efeito, o art. 41 do Código de Processo Penal estatui que a denúncia conterá a exposição do fato criminoso, com todas as suas circunstâncias, a qualificação do acusado ou esclarecimentos pelos quais se possa identificá-lo, a classificação do crime e, quando necessário, o rol das testemunhas. Trata-se de redação abreviada quando comparada aos seus antecedentes históricos, dos quais constava - além da referência ao "facto criminoso com todas as suas circumstancias", "valor provavel do damno soffrido", "nome do delinquente, ou os signaes característicos" e "nomeação de todos os informantes, e testemunhas" -, com especial destaque, "as razóes de convicção, ou presumpção" e o "tempo, e o lugar, em que foi o crime perpetrado" (art. 79 da Lei de 29 de novembro de 1832).

Ao n. 305 de seu Processo Criminal, o Min. Joáo Mendes De Almeida Júnior observou, já à luz do semelhante art. 42 da Parte Segunda do Decreto n. ${ }^{\circ} 3.084 / 1898$, que tanto a queixa quanto a denúncia consistiam em exposição narrativa e demonstrativa. Narrativa porque devem:

"revelar o facto com todas as suas circumstancias, isto é, não só a acção transitiva, como a pessoa que a praticou (quis), os meios que empregou (quibus auxiliis), o malefício que produzio (quid), os motivos que o determinaram a

\footnotetext{
34 RHC 72.074/MG, 5a Turma, Rel. Min. Ribeiro Dantas, julgado em 06/10/2016.

35 Interessante observar que a doutrina italiana tem avançado consideraçóes sobre as sutilezas contidas no exercício do poder-dever de acusar em desconformidade, não com a legislação processual penal explícita, mas com a teleologia implícita à dedução de um pedido condenatório através do processo. Trata-se da tentativa de enquadrar determinadas práticas judiciárias do Ministério Público daquele país no conceito de "abuso de direito", ora sob a perspectiva do "abuso del processo" - por exemplo, quando o ato ilícito reside na procrastinação de inscrever a notizia di reato e inaugurar a fase de investigação sob controle judicial (art. 335, $\mathrm{CPPI}$ ), requestando, todavia, medidas altamente interventivas que, por essa particularidade, se convertem em censuráveis mezzi di acquisizione da própria notitia criminis -, ora sob a perspectiva do "abuso nel processo" - por exemplo, quando o Ministério Público retarda a data da inscrição da notizia di reato com o propósito de alargar os dezoito meses ordinariamente previstos como durata massima delle indagini preliminari (art. 407, CPPI). Sobre o assunto, confira-se a recentíssima obra de SANTORIELLO, C. L'abuso del processo. Pisa: PUP, 2018, pp. 73-142 passim.
} 
isso (cur), a maneira porque o praticou (quomodo), o logar onde o praticou (ubi), o tempo (quando). Demonstrativa, porque deve descrever o corpo do delicto, dar as razóes de convicção ou presumpção e nomear as testemunhas e informantes" 36 .

Bem de ver que o nível de exigência quanto à peça inauguradora da açáo penal de iniciativa pública náo se alterou após o advento do vigente Decreto-Lei n. ${ }^{\circ}$ 3.689/1941, a despeito do que pudesse sugerir a redação mais concisa do art. 41 do atual Código de Processo Penal. Passou-se a definir a denúncia, então, como a "exposição, por escrito, de fato subsumível em um tipo, com a manifestação expressa da vontade de que se aplique a lei penal a quem se suspeita seja o autor, e indicaçáo das provas em que se alicerça a pretensão punitiva" ${ }^{37}$. Refiro, ao propósito, o escólio de Espínola Filho, segundo o qual a "exposição do fato criminoso, com as suas circunstâncias, envolve, naturalmente, a necessidade de referir o dia, e, sempre que possível, a hora, quando o fato se passou, bem como o lugar onde se registrou" 38 .

É que a acusaçáo, consoante enfatizou Frederico Marques, se apresenta como ato fundamental do processo penal condenatório à medida que delimita o fato delituoso e, por via de consequência, a área em que deve incidir a prestaçáo jurisdicional ${ }^{39}$. Noutro modo de dizê-lo:

\footnotetext{
"ação, que é atividade do acusador, e a sentença, que é ato jurisdicional, têm na acusação uma espécie de denominador comum. E o mesmo se diga da defesa, pois as alegaçóes do réu são contra a pretensão constante do pedido acusatório. Isso significa que a acusação, em última análise, constitui o próprio objeto do processo, além de ser sua mola propulsora e a ratio essendi de sua configuração" ${ }^{40}$.
}

36 ALMEIDA JÚNIOR, J. M. Processo criminal brazileiro. Rio de Janeiro: Baptista de Souza, 1920, p. 195. Grifei. As mesmas expressões latinas são encontráveis no $₫ 40$ de SIQUEIRA, G. Curso de processo criminal. São Paulo: Magalhães, 1937, p. 321. A conexão histórica dessas expressôes com a Ars brevis de Raimundo Lúlio é exemplarmente descrita pelo erudito TORNAGHI, H. Instituiçóes de processo penal. São Paulo: Saraiva, 1977, p. 259.

$37 \quad$ NORONHA, E. M. Curso de direito processual penal,1990, p. 27.

38 ESPÍNOLA FILHO, E. Código de processo penal brasileiro anotado. Rio de Janeiro: Editora Rio, 1976, pp. 418-419. Grifei. As referências são, de fato, numerosas. Rememoro, nesse sentido, a lição de HÉLIO TORNAGHI, para quem à acusaçáo incumbe a "exposição minuciosa, não apenas do fato infringente da lei, como também de todos os acontecimentos que o cercaram, não somente de seus acidentes, mas ainda das causas, efeitos, condiçóes, ocasiấo, antecedentes e consequentes. A narrativa circunstanciada ministra ao juiz elementos para um juízo de valor. Bonum ex integra causa, malum ex quocumque defectu. Para que o ato humano seja considerado bom, força é que o seja tanto no essencial quanto no acidental" (TORNAGHI, H. Instituiçóes de processo penal. São Paulo: Saraiva, 1977, p. 328. ). Noutras palavras, "a queixa ou denúncia deve fazer a exposição do crime, descrevendo o fato principal em seus vários episódios, com referência do tempo e lugar em que ocorreu e todas as circunstâncias que o cercaram, de modo a tornar possível a reconstruçáo de todos os acontecimentos que se desenrolaram" (CÂMARA LEAL, A. L. da. Comentários ao código de processo penal brasileiro. Rio de Janeiro: Freitas Bastos, 1942, p. 190).

39 Já se disse, ao respeito, que "denunciar bem é tão importante, que seria preferível pedir a soltura do preso em flagrante, por exemplo, do que imediatamente denunciar, num caso que encerra complexidade” (TOVO, P. C.; TOVO, J. B. M. Apontamentos e guia prático sobre a denúncia no processo penal brasileiro. Rio de Janeiro: Lumen Juris, 2008, p. 52).

40 MARQUES, J. F. Elementos de direito processual penal, 2000, p. 185. Grifei. 
Moderna doutrina tem entendido que as circunstâncias referidas pelo art. 41 do Código de Processo Penal denotam elementos fáticos de duas espécies principais: (a) elementos essenciais, "aqueles necessários para identificar a conduta como fato típico; devem estar presentes na peça acusatória, já que a falta de um deles significa descrição de fato não criminoso, sendo evidente o prejuízo à defesa, que tem direito a ver o fato delituoso inteiramente exposto"; e (b) elementos acidentais, que individualizam a infraçáo com relação a outras infraçóes de mesma natureza, diferençando-os no tempo e espaço de outras infraçôes semelhantes. ${ }^{41}$

No âmbito do egrégio Tribunal Regional Federal desta $1^{a}$ Região, em um dos acórdãos atinentes à "Operação Zelotes", o eminente Des. Fed. Néviton Guedes observou que a denúncia desempenha, no mínimo, duas funçôes: (a) em primeiro lugar, cumpre a funçáo de informação (Informationsfunkton), mediante a qual a acusaçáo deve oferecer e transmitir ao acusado o adequado conhecimento da acusaçáo contra ele dirigida, de modo a propiciar-lhe a ampla defesa e o contraditório, sabendo com clareza do que se deve defender; (b) em segundo lugar, exige-se que a denúncia cumpra a funçáo de delimitaçáo (Umgrenzungsfunktion), de modo a revelar a concretizaçáo do delito, demarcando-lhe, objetiva e subjetivamente, todas as fronteiras, permitindo ao acusado e ao Poder Judiciário destacá-lo com precisão e clareza ${ }^{42}$.

Essas consideraçôes assumem maior relevância quando, nas palavras de Joaquim Canuto, "o contraditório representa, pois, o complemento e o corretivo da ação da parte. Cada um dos contendores age no processo tendo em vista o próprio interesse: a açáo combinada dos dois serve à justa composição da lide” ${ }^{3}$.

Célebres sáo os precedentes do Supremo Tribunal Federal a propósito da matéria, dos quais destaco, entre outros, aqueles em que se decidiu que a pessoa sob investigaçáo penal tem o direito de náo ser acusada com base em denúncia inepta, razão pela qual a:

"denúncia deve conter a exposição do fato delituoso, descrito em toda a
sua essência e narrado com todas as suas circunstâncias fundamentais. Essa
narraçáo, ainda que sucinta, impóe-se ao acusador como exigência derivada
do postulado constitucional que assegura, ao réu, o exercício, em plenitude,
do direito de defesa. Denúncia que deixa de estabelecer a necessária vincula-
ção da conduta individual de cada agente aos eventos delituosos qualifica-se
como denúncia inepta. [...] A mera invocação da condição de diretor ou

41 LIMA, R. B. de. Manual de processo penal. Salvador: Juspodivm, 2018, pp. 300-301. Interessante julgado, nesse sentido, anotou ser inepta a denúncia que "não descreveu qual a conduta praticada pelo paciente, que decorreria de negligência, imprudência ou perícia, a qual teria ocasionado a produção do resultado naturalístico. $O$ fato de o paciente ter perdido o 'controle da direção' e ter, em consequência, invadido a contramão, não é típico. A tipicidade, se houvesse, estaria na causa da perda do controle do veículo. Essa, entretanto, não é mencionada na peça acusatória” (HC 188.023/ES, 6a Turma, Rel. Min. Sebastiâo Reis Júnior, julgado em 01/09/2011).

TRF/1a Região, HC 0050412-71.2017.4.01.0000/DF, 4a Turma, Rel. Des. Fed. Néviton Guedes, e-DJF1 de 19/12/2017.

43 ALMEIDA, J. C. M. de. Princípios fundamentais do processo penal, 1973, p. 79. 
de administrador de instituição financeira, sem a correspondente e objetiva descrição de determinado comportamento típico que o vincule, concretamente, à prática criminosa, não constitui fator suficiente apto a legitimar a formulação de acusação estatal ou a autorizar a prolação de decreto judicial condenatório" ${ }^{44}$.

O presente estágio do constitucionalismo brasileiro (art. 5º, LV, CRFB/88) e da convencionalidade interamericana (art. $8^{\circ} \mathrm{da} \mathrm{CADH}$ ) impóe, lado outro, a releitura dessas exigências à luz do postulado do devido processo penal, consubstanciado no asseguramento do contraditório e da ampla defesa, com os meios e recursos a ela inerentes. A perspectiva a que se dedica este ensaio, ao mesmo tempo em que debela o laxismo dogmático no controle jurisdicional da pretensão acusatória, guarda harmonia com o sistema interamericano de tutela dos direitos humanos.

Inobstante a praxe jurisdicional laxista na prefacial análise das denúncias oferecidas possa convergir a propósitos estatísticos e à gestáo emergencial de grandes acervos processuais fomentada, de um lado, pela subsistência de uma concepção não-decisória do recebimento da denúncia, do qual derivaria a inexigibilidade de fundamentação ${ }^{45}$; de outro, pela invocação do "princípio in dubio pro societate" ${ }^{46}$-, é bem de ver que o advento da Lei n.o 11.719/2008 introduziu hipóteses de imperativa rejeição da denúncia.

44 HC 84580/SP, 2a Turma, Rel. Min. Celso de Mello, julgado em 25/08/2009. Grifei. Noutro histórico precedente, o Min. Celso de Mello observou: "O abuso de poder no oferecimento da denuncia, desde que inexista qualquer incerteza objetiva em torno dos fatos subjacentes a instauração da persecução penal, revela-se suscetível de controle jurisdicional pela via do habeas corpus. [...] Existe, na perspectiva dos princípios constitucionais que regem o processo penal, um nexo de indiscutível vinculação entre a obrigação estatal de oferecer acusação formalmente precisa e juridicamente apta e o direito individual de que dispóe o acusado a ampla defesa. A imputação penal omissa ou deficiente, além de constituir transgressão do dever jurídico que se impóe ao Estado, qualifica-se como causa de nulidade processual absoluta. A denúncia - enquanto instrumento formalmente consubstanciador da acusaçáo penal - constitui peca processual de indiscutível relevo jurídico" (HC 70763/DF, 1a Turma, Rel. Min. Celso de Mello, julgado em 28/06/1994 - grifei).

$45 \quad$ Superficial análise da jurisprudência dos Tribunais Superiores permite constatar, ainda em recentes precedentes e mesmo depois das reformas legislativas que arrolaram as hipóteses de necessária rejeição da denúncia, acórdãos que referem o caráter não-decisório do recebimento da denúncia. No âmbito do Supremo Tribunal Federal, exemplificativamente: ARE 845341 AgR, 2a Turma, Rel. Min. Dias Toffoli, julgado em 08/09/2015; e HC 118183, 2a Turma, Rel. Min. Cármen Lúcia, julgado em 10/12/2013. Entretanto, salvo melhor juízo, "com a previsão da apresentação da defesa preliminar (ou resposta escrita) em alguns procedimentos, a decisão que receber a denúncia ou queixa deverá, ainda que sucintamente, refutar os argumentos apresentados pelo acusado. Se assim não fosse, de nada valeria a previsão dessa peça de defesa" (DEMERCIAN, P. H.; MALULY, J. A. Curso de processo penal. Rio de Janeiro: Forense, 2014, p. 120).

46 Enigmática expressão tendente a afirmar que, havendo dúvida a respeito da admissibilidade prefacial da imputação delitiva, o magistrado deve privilegiar a persecução e, por isso, deflagrar a ação penal. A expressão é amplamente encontradiça na jurisprudência brasileira. No Supremo Tribunal Federal, veja-se, por exemplo, o HC 105251/RJ, 2a Turma, Rel. Min. Ellen Gracie, julgado em 28/06/2011. No Superior Tribunal de Justiça: RHC 89.461/AM, 5a Turma, Rel. Min. Felix Fischer, julgado em 17/05/2018; HC 362.881/RJ, 6a Turma, Rel. Min. Sebastião Reis Júnior, julgado em 10/11/2016. No âmbito dos Tribunais Regionais Federais, exemplificativamente: TRF/1a Regiāo: ACR 00046297720144013810/MG, 3a Turma, Rel. Juiz Fed. Conv. Leão Aparecido Alves, e-DJF1 de 20/03/2018; ACR 0009965-91.2015.4.01.3304 /MG, 4a Turma, Rel. Juiz Fed. Conv. Guilherme Fabiano Julien de Rezende, e-DJF1 de 14/02/2017; TRF/4ª Regiáo: RSE 5010445-97.2016.4.04.7205/SC, 7a Turma, Rel. Des. Fed. Salise Monteiro Sanchotene, julgado em 13/03/2018; RSE 5050533-70.2017.4.04.7100/RS, 8a Turma, Rel. Des. Fed. Leandro Paulsen, julgado em 07/03/2018. 
Com efeito, a teor do art. 395 do Código de Processo Penal, a denúncia ou queixa será rejeitada quando for manifestamente inepta; faltar pressuposto processual ou condiçáo para o exercício da ação penal; ou faltar justa causa para o exercício da ação penal.

O primeiro inciso, ao cuidar da inépcia manifesta, é objeto de relativa controvérsia doutrinária, podendo ser contemplada como causa mais ampla de rejeição, albergando a falta de condições da ação ou mesmo de justa causa para o exercício da ação penal. Alguns autores entendem inepta a denúncia que, a exemplo do que sucede no Código de Processo Civil, não descrever fato criminoso, náo imputar fatos determinados ou da exposiçáo náo resultar logicamente a conclusão ${ }^{47}$. Outros, que o fenômeno pode se desmembrar em inépcia formal - quando a incoativa não preenche os requisitos obrigatórios do art. 41 do Código de Processo Penal - e inépcia material, em que a carência de lastro probatório mínimo assemelharia à falta de justa causa ${ }^{48}$. Outros, ainda, que se configura a:

\footnotetext{
“inépcia da peça acusatória quando náo se prestar aos fins aos quais se destina, vale dizer, não possuir a menor aptidáo para concentrar, concatenadamente, em detalhes, o conteúdo da imputaçáo, permitindo ao réu a exata compreensão da amplitude da acusação, garantindo-lhe, assim, a possibilidade de exercer o contraditório e a ampla defesa" ${ }^{39}$.
}

Refiro, por ilustrativo, uma das denúncias endereçadas em desfavor do senador Renan Calheiros, inadmitida pelo Supremo Tribunal Federal, o qual, em sua composição plenária, decidiu ser "inepta a denúncia que imputa genericamente o crime de falsidade ideológica ao acusado sem esclarecer, no conjunto de documentos por ele apresentados ao Conselho de Ética do Senado, especificamente qual documento contém informação falsa" ${ }^{50}$. O Superior Tribunal de Justiça, de igual forma, possui variegados acórdãos salientando a necessidade de se contextualizar a participação do(s) denunciado(s) na suposta

\footnotetext{
$47 \quad$ GRECO FILHO, V. Manual de processo penal, 2017, p. 150.

48 LIMA, R. B. de. Manual de processo penal. Salvador: Juspodivm, 2018, p. 1.311. Em sentido diverso, entendendo que o primeiro inciso cuida exclusivamente da inépcia formal (ao passo que a inépcia material estaria contemplada no art. 395, III, CPP), a posição de MENDONÇA, A. B. de. Dos processos em espécie. In: GOMES FILHO, A. M.; TORON, A. Z.; BADARÓ, G. H. (Coords.). Código de processo penal comentado. São Paulo: RT, 2018, p. 715.

49 NUCCI, G. de S. Código de processo penal comentado, 2017, p. 945. Grifei.

50 Inq 2593, Pleno, Rel. Min. Edson Fachin, julgado em 01/12/2016. Grifei.
} 
atuação criminosa, sejasoba perspectiva dadelimitaçãosubjetiva da concorrênciadedesígnios ouaçóes $^{51}$, sejasoboângulodoobjetivoenquadramentodascondutasàluzdostiposirrogados ${ }^{52}$.

Ao perspectivar o segundo inciso à luz das categorias próprias do Direito Processual Penal, Aury Lopes Jr. propóe que as condiçóes a que alude o art. 395, II, do Código de Processo Penal devem ser compreendidas como:

(a) prática de fato aparentemente criminoso (fumus comissi delicti), vale dizer, incumbe à acusação a demonstração da tipicidade aparente da conduta, sem prejuízo de que, havendo elementos indiciários que o acusado agiu, manifestamente, ao abrigo de causa excludente de ilicitude ou de culpabilidade, o juiz se antecipe à fase da absolvição sumária (art. 397, III, CPP) e rejeite a denúncia;

(b) punibilidade concreta, de sorte que, demonstrada icto oculi a causa extintiva da punibilidade (art. 107, CP), mister a rejeição da denúncia, reservada a absolvição sumária para os casos em que essa prova

\footnotetext{
$51 \quad$ Já se reputou inepta a denúncia (a) na qual "não se demonstrou de que forma os recorrentes concorreram para a ocorrência do fato delituoso a eles imputados na acusação, ou seja, não se demonstrou o mínimo vínculo entre os acusados e o crime a eles imputados, ou mesmo o vínculo entre eles para a prática dos delitos, impossibilitando, com isso, o exercício do contraditório e da ampla defesa” (RHC 73.096/SP, 6ª Turma, Rel. Min. Sebastiáo Reis Júnior, julgado em 21/09/2017); (b) que "apontou a prática de diversos ilícitos ao paciente sem sequer precisar qual a conduta cometida por ele, somente destacando que seria o "contador da organização criminosa”, sem particularizar as ações que embasassem tal consideração, prejudicando, assim, o exercício da mais ampla defesa” (HC 178.577/MS, 6a Turma, Rel. Min. Maria Thereza De Assis Moura, julgado em 20/08/2013); (c) que "náo descreve, de maneira devida, qual foi o atendimento médico imediato e especializado que a recorrente poderia ter prestado (e que náo tenha sido suprido por outro profissional) e que pudesse ter evitado a morte da paciente, bem como não descreve que circunstância $(\mathrm{s})$ permite $(\mathrm{m})$ inferir que tenha ela previsto o resultado morte e a ele anuído. Nas imputaçóes pela prática de crime comissivo por omissão, para que se configure a materialidade do delito, é imprescindível a descrição da conduta (omitida) devida, idônea e suficiente para obstar o dano ocorrido. Em crime de homicídio, é mister que se indique o nexo normativo entre a conduta omissiva e a morte da vítima, porque só se tem por constituída a relação de causalidade se, com lastro em elementos empíricos, for possível concluir-se, com alto grau de probabilidade, que o resultado náo ocorreria se a ação devida (no caso vertente, o atendimento imediato pela recorrente) fosse realizada. Se tal liame, objetivo e subjetivo, entre a omissão da médica e a morte da paciente não foi descrito, a denúncia é formalmente inepta, porquanto não é lícito presumir que do simples não comparecimento da médica ao hospital na noite em que fora chamada para o atendimento emergencial tenha resultado, 3 (três) dias depois, o óbito da paciente" (RHC 39.627/RJ, 6a Turma, Rel. Min. Rogério Schietti Cruz, julgado em 08/04/2014).
}

52 Reputou-se inepta a denúncia quando, tendo listado vinte e dois documentos falsificados, imputou a falsificação de doze, haja vista a ausência de individualização do objeto da imputação (HC 76.098/MG, 6a Turma, Rel. Min. Maria Thereza de Assis Moura, julgado em 06/04/2010). Interessantíssima, outrossim, é a intersecção do tema com as normas penais em branco, em relação às quais o Superior Tribunal de Justiça entende ser necessária a indicação: (a) das portarias proibitivas, relativamente ao crime de contrabando (AgRg nos EDcl no REsp 1521645/CE, 5a Turma, Rel. Min. Reynaldo Soares Da Fonseca, julgado em 15/08/2017); (b) dos atos regulatórios extrapenais, referidos pelo art. 1º, I, da Lei n. ${ }^{\circ}$ 8.176/1991 (AgRg no HC 249.472/MG, 5a Turma, Rel. Min. Joel Ilan Paciornik, julgado em 21/11/2017; HC 350.973/SP, 6a Turma, Rel. Ministro Néfi Cordeiro, julgado em 09/08/2016); (c) do ato normativo definidor das armas e muniçóes de uso restrito, para fins de incidência do art. 16 da Lei 10.826/2003 (RHC 79.787/MT, 5a Turma, Rel. Min. Reynaldo Soares da Fonseca, julgado em 13/06/2017); (d) do ato regulatório dos níveis tolerados de sonoridade, para fins de caracterização da poluição sonora prevista no art. 54 da Lei n.o 9.605/1998 (HC 240.249/MG, 6a Turma, Rel. Min. Rogério Schietti Cruz, julgado em 24/02/2015). 
venha aos autos após o recebimento da denúncia (art. 397, IV, CPP);

(c) legitimidade das partes, quer sob o ângulo ativo (exame da titularidade da ação penal), quer sob o ângulo passivo (relacionado à suposta autoria do fato tido como delituoso $)^{53}$.

Quanto à justa causa referida pelo terceiro inciso do art. 395 do Código de Processo Penal, cuja nebulosa definiçáo parece ter reclamado do legislador assento apartado das demais condiçóes da ação penal, abalizada doutrina tem-na caracterizado como "justa razão ou razão suficiente para instauração da ação penal”, subdividida na existência de fundamentos de fato e de direito para a acusação.

O fundamento de direito para a acusação pressupóe que a ordem jurídica aceite a limitação à liberdade jurídica; já a existência do fundamento de fato pressupóe que a denúncia ou queixa guarde fidelidade para com o inquérito policial ou elementos de informação, relacionados com a existência material do fato, indícios suficientes de autoria e um mínimo de culpabilidade ${ }^{54}$.

Noutras palavras:

\begin{abstract}
"a justa causa não se limita apenas a um suporte probatório mínimo, ou se restringe ao conceito de interesse de agir, ou representa a presença de tipicidade. Ela é tudo isso, mas não é apenas isso. A justa causa é uma cláusula de encerramento, que concretiza, no âmbito processual penal, os preceitos constitucionais de dignidade, da proporcionalidade [...] Ela concretiza a legitimidade de submeter alguém a um processo criminal sob todas
\end{abstract}

\footnotetext{
$53 \quad$ LOPES JR., A. Direito processual penal. São Paulo: Saraiva, 2017, pp. 193-198 passim. Observando os estreitos limites temáticos deste artigo, reporto-me, a respeito deste controverso capítulo da teoria do processo penal, às obras de maior fôlego doutrinário que dele cuidaram com o devido vagar. Por todos, confira-se: BADARÓ, G. H. As condiçôes da ação penal. In: ZUGELATO, C.; YARSHELL, F. L. (Orgs.). 40 anos da teoria geral do processo no Brasil: passado, presente e futuro. São Paulo: Malheiros, 2013, pp. $171 \mathrm{et} \mathrm{seq.}$

54 MOURA, M. T. R. de. Justa causa para açáo penal. São Paulo: RT, 2001, p. 291. Essa dicotomia pode ser entrevista, igualmente, na (a) existência de indícios razoáveis de autoria e materialidade, a contrario sensu dos artigos 12, 39, $\$ 5^{\circ}, 46, \S 1^{\circ}, 648$, I, todos do Código de Processo Penal; e no (b) controle processual do caráter fragmentário da intervenção penal, traduzido no necessário controle, exercido pelo magistrado, tocante à proporcionalidade entre os elementos que justificam a intervençáo penal e processual, de um lado, e o custo do processo penal, de outro (LOPES JR., Aury. Direito processual penal. 14.ed. Sáo Paulo: Saraiva, 2017, p. 197). Em sentido semelhante, substancializando essa categoria processual com as cargas teleológicas da pena, a advertência de Fauzi Choukr, para quem a justa causa "funciona como um mecanismo de adesão ao processo penal constitucional, visto que impede o exercício abstrato da Justiça criminal, condicionando seu fundamento a uma concreta demonstraçáo da necessidade da recomposição do mundo da vida pela aplicação de uma pena que atenda às suas finalidades estritas num Estado Democrático e de Direito" (CHOUKR, F. H. Código de processo penal. Comentários consolidados \& crítica jurisprudencial. Belo Horizonte: D’Plácido, 2017, p. 38).
} 
as perspectivas exigidas pela ordem constitucional" ${ }^{55}$.

Articuladas a dimensão convencional e a dimensão legal do direito a ser bem acusado no processo penal brasileiro, pretendo, agora, confrontá-las com a prática jurisdicional brasileira relativamente a certas denúncias formuladas em desfavor de gestores públicos, não sem antes explorar os superiores atributos epistemológicos do contraste entre as premissas teóricas da primeira parte com a análise de casos concretos, iluminando, na segunda parte, os caracteres verdadeiramente punitivos da imputação de responsabilidade penal objetiva.

\section{PUNIR}

\subsection{Relevância epistemológica da casuística forense}

Ao conjurar a pecha de abstracionismo metafísico que se lançava contra a Declaração Universal dos Direitos Humanos de 1948, o memorável Giuseppe Capograssi, jusfilósofo e membro da Corte Constitucional italiana, advertia que, obnubiladas as origens profundas dessas declaraçóes nos eventos mais centrais da história contemporânea, seu significado esvaneceria e neles só se leriam tautologias e repetiçôes de fórmulas envelhecidas. Ao contrário, é da experiência concreta das hecatombes experimentadas ao longo do séc. XX que se ergue o exercício reflexivo radical a propósito das necessidades normativas comuns à humanidade ${ }^{56}$.

Nessa linha intelectiva, visando a emprestar concretude analítica ao enfrentamento do tema, depois de terem sido expostas, na primeira parte, (1.1) os caracteres jurídicoconvencionais que conformam o direito a ser bem acusado e sua (1.2) ascendência normativa sobre o tratamento sistêmico da acusaçáo no processo penal, parece-me interessante cotejá-los, nesta segunda parte, com a complexidade que a casuística fo-

55 CARVALHO, L. G. G. C. de. Processo penal e constituiçáo. 2014, p. 227. Grifei. No âmbito do Supremo Tribunal Federal, a justa causa tem sido entendida como "exigência de suporte probatório mínimo a indicar a legitimidade da imputaçáo e se traduz na existência, no inquérito policial ou nas peças de informação que instruem a denúncia, de elementos sérios e idôneos que demonstrem a materialidade do crime, bem como de indícios razoáveis de autoria". Ou, ainda, como "ônus da acusaçáo de demonstrar, ainda que superficialmente, porém com fundamento de relativa consistência, nesta fase preliminar do processo, os fatos constitutivos sobre os quais se assenta a pretensáo punitiva do Estado" (Inq 3507, Pleno, Rel. Min. Gilmar Mendes, julgado em 08/05/2014 - grifei).

56 Malgrado o exemplar consultado não traga a deliciosa prosa italiana do maestro, sua tradução francesa exprime, em grau menor, a eloquência de seu primoroso discurso a respeito da trágica linha de causalidade histórica entre a Declaração e a mortandade da 2a Guerra Mundial: "La vérité est que ces documents, tels qu'ils sont, et surtout la presente 'Déclaration universelle', sont typiquement liés et adaptés à toute l'expérience contemporaine; ils entendent donner un détermination et une expression aux besoins objectifs et élémentaires que l'humanité a perçus, éclairée par les expériences qu'elle a faites. Le contenu de la presente déclaration ne vient pas de déductions abstraites, il ne renvoie pas à de vieilles métaphysiques ni à de vieux catalogues de droit naturel: il est dicté par les besoins les plus nets de nos sociétés, et proportionné aux faits les plus retentissants et aux exigences les plus vitales de l'humanité presente. Telle qu'elle est, la Déclaration est pour ainsi dire l'acte de réflexion le plus puissant que les Nations Unies aient mené sur l'expérience historique des sociétés contemporaines: le jugement profond que les Nations elle-mêmes ont porté à partir des difficultés que leurs peuples ont subies" (CAPOGRASSI, G. La Déclaration Universelle des Droits de l'Homme et sa signification. In: L'expérience juridique. Traduit de l'italien par Christophe Carraud. Paris: Conférence, 2016, p. 88). 
rense oferece ao intérprete. Valho-me, para tanto, da experiência haurida da jurisdição criminal de fronteira na Vara Federal da Subseção Judiciária de Tabatinga/AM, município distante há mais de um milhar de quilômetros da capital manauara, onde parece viger um "processo penal de fronteira" 57 .

Com efeito, a singela constatação de que a efetividade do fenômeno punitivo depende do desenvolvimento do devido processo penal ${ }^{58}$ aponta para a relevância de que se reveste a análise, por intermédio de casos concretos, do diritto penale giurisprudenziale ${ }^{59}$. Na literatura tedesca, por exemplo, Harro Otto se dedicou à abordagem da imprescindibilidade não apenas didática, mas verdadeiramente epistemológica da integração do raciocínio jurídico com a feitura de "exercícios", ou seja, o desempenho da vocação essencialmente prática da ciência do direito ${ }^{60}$.

Por essas razóes, associo-me à iniciativa pragmática de grandes penalistas contemporâ${ }^{n e o s}{ }^{61}$ para afirmar que as consideraçóes teóricas sobre a relevância da previsáo contida no art. $8^{\circ}$ da CADH sáo insuficientes, por si sós, à sua efetivaçáo no ordenamento jurídico brasileiro. O laxismo dogmático a que me referi anteriormente deve ser confrontado em sua dinâmica operacional concreta e, para tanto, bastam alguns poucos exemplos aos quais se dedica o próximo subcapítulo.

\footnotetext{
$57 \quad$ Sobre as subsistemáticas do processo penal brasileiro e do "processo penal de fronteira" - entendido, este, como o conjunto de práticas que caracterizam a abordagem institucional dos crimes perpetrados nas zonas fronteiriças do país, muita vez incompatíveis com as balizas legais e constitucionais que delineiam o perfil dogmático do processo penal brasileiro -, confira-se LEAL, B. H. Processo penal de fronteira. Tópicos de experiência jurisdicional na Subseção de Tabatinga/AM. In: Revista do Tribunal Regional Federal da Primeira Regiáo. 2018, p. 17-37.
}

58 A respeito das conexóes entre o caráter necessariamente processual do fenômeno punitivo de origem estatal, sintetizado no brocardo nulla poena sine judicio, vejam-se as consideraçóes de FERRAJOLI, L. Derecho y razón. Teoría del garantismo penal. Traducido por Perfecto Andrés Ibánez et al. Madrid: Trotta, 2016. pp. 537 et seq.

59 FIANDACA, G. Prima lezione di diritto penale, 2017, p. 132.

60 É que, segundo o autor, a contemplação isolada das técnicas de subsunção, posto que valorize sua natureza de pressuposto do trabalho científico, impede que se responda à questão de saber se os fatos citados na lei realmente correspondem aos fatos a serem avaliados No vernáculo, com explícita referência à linguagem de KARL ENGISCH: "Subsumtion und formale Regeln (z.B. argumentum e contrario, argumentum a maiore ad minus) sind nur Hilfsmittel bei dieser Feststellung. Das 'Hin- und Herwandern des Blickes' [...] zwischen Norm und Lebenssachverhalt ist gerichtet auf ein Verstehen der zwischen ihnen bestehenden Entsprechung” (OTTO, H. Übungen im Strafrecht. Berlin: De Gruyter, 2005, p. 03).

61 Aludo à opção metodológica da dissecação dos "grandes temas" do direito penal e processual penal a partir da análise de casos concretos, encampada, por exemplo no tratamento da imputaçáo objetiva, por Luís Greco (com destaque às páginas 105 e seguintes de GRECO, L. Um panorama da teoria da imputaçáo objetiva. Sáo Paulo: RT, 2014); do erro de proibiçáo, por Alaor Leite (às páginas 02 a 05 de LEITE, A. Dúvida e erro sobre a proibiçáo no direito penal. A atuação nos limites entre o permitido e o proibido. São Paulo: Atlas, 2014); da dosimetria da pena, por Adriano Teixeira (páginas 25-28 e 177-181 de TEIXEIRA, A. Teoria da aplicação da pena. Fundamentos de uma determinação judicial da pena proporcional ao fato. São Paulo: Marcial Pons, 2015); do princípio da confiança em direito penal, por Flavia Siqueira (páginas 27 a 37 de SIQUEIRA, F. O princípio da confiança no direito penal. Belo Horizonte: D’Plácido, 2016). No direito comparado, antiga obra de VANNINI, O. Come deve essere praticamente insegnata la procedura penale. Milano: Giuffrè, 1951; além de BACIGALUPO, E. Técnica de resolución de casos penales. Buenos Aires: Hammurabi, 1990, pp. 25-90 e 105-132 passim. 


\subsection{Responsabilidade penal objetiva de gestores públicos}

Consoante declinei nas consideraçóes introdutórias deste artigo, endereço este segundo momento da segunda parte à operacionalidade concreta do direito convencional a ser bem acusado, à medida que espartilho o foco analítico sobre um determinado tipo de agente e um determinado tipo de delito, os quais, submetidos à severa desaprovaçáo popular, ganharam expressiva notoriedade no cenário brasileiro do último decênio, sobretudo a partir da AP 470/MG (Caso Mensaláo) e da "Operação Lava-Jato"62.

Refiro-me às denúncias que irrogam contra gestores públicos a responsabilidade penal pela suposta malversação de valores sob as mais diversificadas capitulaçôes. E, ao fazê-lo, passo a analisar, a título exemplificativo, dois tipos penais de expressiva significação estatística no acervo da Subseção Judiciária de Tabatinga/AM: a imputaçáo do (1) crime de sonegação de contribuição previdenciária descontada no contracheque dos servidores municipais (art. 337-A, CP) e do (2) extravio, sonegação ou inutilização de livro ou documento (art. 314, CP).

\section{Quanto à (1) sonegaçáo de contribuiçáo previdenciária descontada do contracheque} dos servidores municipais - cuja tipificação à luz do art. 337-A, I, do Código Penal já se mostra, de saída, problemática ${ }^{63}$-, muitas são as denúncias oferecidas sem que de seu exame prefacial se possa extrair por qual meio o acusado suprimiu ou reduziu contribuição social previdenciária, restringindo-se, a narrativa acusatória, a indicar matematicamente a

62 A propósito desses e de outros casos congêneres, à luz das liçốes de Luís Greco sobre a famigerada construção jakobsiana do "Feindstrafrecht", confira-se LEAL, Bruno Hermes. Inimigos e Corruptos: prescindibilidade do "direito penal do inimigo" e alternativas dogmáticas ao enfrentamento da corrupção brasileira. In: Anais do XIV Seminário Internacional Demandas Sociais e Políticas Públicas na Sociedade Contemporânea. Santa Cruz do Sul: UNISC, 2018. No prelo.

63 Adotando como paradigma a tipicidade objetiva do art. 337-A, I, do Código Penal, a primeira questão que salta aos olhos diz com a aparente incompatibilidade entre o elemento normativo "empresa" - a designar exercício profissional de atividade econômica organizada para a produção ou a circulação de bens ou de serviços (art. 966, CC) - e a administração municipal de uma pessoa jurídica de direito público interno (art. 41, III, CC). Essa contradição não escapou da argúcia do eminente Des. Fed. Olindo Menezes, segundo o qual, em brilhante precedente, "o tipo do art. 337-A, I e II do Código Penal faz referência a 'empresa' como elemento normativo do tipo, no qual não podem ser incluídas as pessoas jurídicas de direito público e seus agentes. Para fins penais, essa equiparação, à míngua de determinação legal expressa, constitui um atentado ao princípio da legalidade (art. 5o, XL - CF e art. $1^{\circ}-\mathrm{CP}$ ). Os agentes políticos não se qualificam como sujeito ativo do crime do art. 337-A, I e II, do Código Penal, que aludem à folha de pagamento e à contabilidade da empresa" (TRF/1 ${ }^{\text {a }}$ Regiáo, RSE 0054034-81.2010.4.01.3500, 4a Turma, Rel. Des. Fed. Olindo Menezes, julgado em 24/07/2013 - grifei). A despeito da justeza dessas consideraçóes, a orientaçáo atual do Superior Tribunal de Justiça trafega no sentido de que "[P] ode qualquer pessoa, particular ou agente público, inclusive prefeitos, praticar o crime do art. 337-A do Código Penal, consistente na omissão de valores na guia de recolhimento do fundo de garantia por tempo de serviço e informação à Previdência Social - GFIP” (RHC 43.741/RJ, 6a Turma, Rel. Min. Nefi Cordeiro, julgado em 10/03/2016). Em caso paradigmático, a eminente Min. Thereza de Assis Moura observou: "[N]ão por outra razão a própria lei penal comporta interpretação analógica determinando que se amplie o seu conteúdo ou alcance ao dispor que constitui sonegação de contribuição previdenciária suprimir ou reduzir contribuição por omissão na folha de pagamento ou de documento de informaçôes previdenciárias relativa à segurado empregado "ou a este equiparado que lhe prestem serviços". Vale anotar, a propósito, o conceito de 'empresa' para fins de Custeio da Previdência Social que está contido na Lei no 8.21291, e que expressamente inclui os órgãos e entidades da administração pública [...] Do exposto, resulta que a possibilidade de responsabilização dos gestores públicos, dentre eles o chefe do executivo municipal, pelo delito de sonegação de contribuição previdenciária não decorre de analogia ou de outra forma de integração da norma porque não se está a criar condutas puníveis, nem a impor penas, mas de necessária e cabível interpretação analógica do dispositivo previsto pelo próprio legislador penal, não havendo falar em violação qualquer do princípio da legalidade estrita” (REsp 1435305/GO, 6a Turma, Rel. Min. Maria Thereza de Assis Moura, julgado em 28/04/2015). 
ausência de repasse dos respectivos valores ao INSS como requisito suficiente à imputação delitiva ao então prefeito ${ }^{64}$.

Ao revés, a perspectiva jurisprudencial predominante tem exigido, muito além do exercício da chefia do Poder Executivo municipal, a indicação de indícios mínimos segundo os quais o acusado tenha concorrido ou determinado a supressão ou redução de contribuição social. Em caso muito semelhante, o Min. Felix Fischer, ao frisar a inépcia da exordial acusatória, anotou:

"a denúncia deve descrever a conduta típica atribuída ao prefeito. Entretanto, observa-se da leitura da peça acusatória, que a imputação foi feita de forma automática, pela simples condição de prefeito do acusado, o que náo se pode admitir" ${ }^{\prime 5}$.

Quanto ao (2) extravio, sonegaçáo ou inutilização de livro ou documento (art. 314, $\mathrm{CP})$, trata-se de acusação reiteradamente extraída de notícia-crime formulada, nos primeiros meses de ano subsequente às eleiçóes municipais, por representantes da agremiação partidária vencedora em desfavor da gestão que acaba de deixar a chefia do Poder

64 Não se cuida, aqui, de problematizar a questão relativa às exigências subjetivas do tipo penal em questão, as quais se restringem - consoante a orientação predominante no âmbito do Superior Tribunal de Justiça (AgRg no AREsp 765.883/SC, 5a Turma, Rel. Min. Joel Ilan Paciornik, julgado em 06/02/2018; AgRg no AREsp 1111582/RS, 6a Turma, Rel. Min. Maria Thereza de Assis Moura, julgado em 12/06/2018) - ao dolo genérico, despicienda a demonstração do animus específico de fraudar a Previdência Social. A inépcia da denúncia, no caso, consiste em falhar na demonstração da tipicidade objetiva, vinculando a sonegação previdenciária ao mero exercício da chefia da administração municipal.

65 REsp 299.831/PE, 5a Turma, Rel. Min. Felix Fischer, julgado em 02/08/2001. Em caso muito semelhante, a $5^{\text {a }}$ Turma do Superior Tribunal de Justiça também decidiu que "o prefeito municipal - quanto aos crimes próprios de sua atuação como agente público, lógico, deve corresponder às condutas próprias das atribuiçóes de seu cargo. Em princípio, não compreende o recolhimento e a transferência das contribuiçóes sociais. A denúncia, por isso, deve descrever, para ser apta, a atribuição legal, ou a participação ideológica do prefeito municipal” (REsp 79.832/RS, 5a Turma, Rel. Min. Luiz Vicente Cernicchiaro, julgado em 02/08/2001). No âmbito do egrégio Tribunal Regional Federal desta $1^{a}$ Região há acórdãos, inclusive, indicando que a sonegação de contribuição previdenciária não pode ser imputada ao prefeito, se náo comprovado o desvio ou apropriação da verba em proveito do agente político (v.g., HC 0015069-53.2013.4.01.0000, $3^{a}$ Turma, Rel. Des. Fed. Cândido Ribeiro, julgado em 06/05/2013; HC 0054110-90.2014.4.01.0000, $3^{\mathrm{a}}$ Turma, Rel. Des. Fed. Ney Bello, julgado em 17/03/2015). Em relevante precedente, decidiu-se que "[À] míngua de indícios, ainda que mínimos, de enriquecimento ilícito decorrente da prática criminosa atribuída ao Paciente na Denúncia, indiscutível a falta de justa causa em relação a ele. 4 - Este Tribunal tem decidido, reiteradamente, que o administrador público somente será responsabilizado, pessoalmente, por infraçôes se conceituadas como crimes ou contravenções, ficando indene se praticadas no exercício regular das suas funções e, evidentemente, pretender responsabilizá-lo por não ter fornecido à fiscalização, mensalmente, guias de recolhimentos e dados cadastrais para verificaçáo da regularidade no recolhimento das respectivas contribuições previdenciárias é inadmissível por não estar entre suas atribuiçôes pessoais, competindo essa tarefa ao Setor responsável pelo recolhimento de encargos vinculados à folha de pagamento de agentes políticos e servidores do município. 5 - Não vinculando a Denúncia proveito pessoal ou acréscimo patrimonial à prática delituosa prevista no art. 337-A, I, do Código Penal, mas apresentando como fundamento da pretensão punitiva, tão somente, o fato de ter sido o paciente prefeito durante o período fiscalizado, deficiente a motivação e, consequentemente, patente constrangimento ilegal a autorizar a concessão da ordem de Habeas Corpus" (TRF/1ª Região, HC 0047216-35.2013.4.01.0000, 3a Turma, Rel. Des. Fed. Catão Alves, julgado em 11/09/2013 - grifei). 
Executivo municipal ${ }^{66}$. A acusação, entáo, sói entrever a configuração dos verbos nucleares típicos na suposta omissáo no exercício responsável da ascendência funcional e hierárquica sobre todos os servidores municipais, perspectiva essa que contrasta não apenas com a aderência eminentemente subjetiva da responsabilidade penal, mas também com a decantada orientação doutrinária ${ }^{67}$ e jurisprudencial a propósito do tipo em questão.

Ora, se da denúncia não se extrai, por qual obrigação legal o ex-prefeito deveria assumir ou avocar a responsabilidade pela guarda de documentos atinentes a certo convênio, impóe-se a indagação sobre qual fato teria deslocado a guarda de documentos atinentes a um deles, entre dezenas de outros, à esfera de responsabilidades da chefia do Poder Executivo, e não ao secretário respectivo ou a algum outro agente subalterno da administração municipal. À míngua da tomada extrajudicial de depoimento que sinalize a existência de ordens do gestor acusado, implícitas ou explícitas, para que alguém promovesse o doloso desaparecimento de tais documentos, por exemplo, exala debilidade a extração da responsabilidade penal da mera condição de prefeito.

Da análise dos exemplos veiculados bem se vê que a frustração do direito convencional a ser bem acusado se articula, nesses casos, ao redor da presunçáo da responsabilidade do chefe da administração municipal pelos mais distintos segmentos de atuação estatal sobre os quais, desde os modestos núcleos populacionais até as grandes concentraçôes urbanas, os prefeitos não exercem qualquer supervisão direta.

Quanto a esses casos exemplificativos, seguramente, não se pode afirmar que tenham sido asseguradas, como exige o art. 8.2 da Convençáo Interamericana sobre Direitos Humanos, a comunicação prévia e pormenorizada da acusaçáo formulada, ou a concessáo do tempo e dos meios adequados ao acusado para a preparaçáo de sua defesa. Isso porque a genérica imputaçáo aos gestores públicos de atos praticados por subordinados seus, sem que se demonstre o concurso de agentes para a prática delitiva, ao mesmo tempo em que descaracteriza a natureza pormenorizada da acusaçáo formulada (a acusação consiste em fato próprio ou na colaboração com fato alheio?), desguarnece o acusado dos meios adequados para a preparação de sua defesa (o acusado deve demonstrar a inexistência de crime seu ou da perfeita regularidade dos serviços prestados por todos os servidores da administraçáo municipal envolvidos no fato?).

\footnotetext{
66 Em caso específico, o egrégio Tribunal Regional Federal desta $1^{\text {a }}$ Região decidiu que "[N]ão consta dos autos indícios mínimos de materialidade e de autoria que evidenciem o extravio dos documentos pelo acusado. A denúncia baseou-se tâo somente no depoimento do sucessor do ex-prefeito, sem que fossem realizadas outras diligências para confirmação da existência de tais documentos e que de fato foram extraviados ou sonegados" (TRF/1a Região, ACR 0001138-19.2014.4.01.3307, 3ª Turma, Rel. Des. Fed. Monica Sifuentes, e-DJF1 de 26/05/2017).

67 A título meramente exemplificativo, registro que, segundo o velho NELSON HUNGRIA, a tipicidade objetiva do crime previsto pelo art. 314 do Código Penal denota crime próprio, cuja consumação pressupóe não apenas a condição funcional, senão a prática "em razão do cargo' (rationi officii), vale dizer, o agente há de ser o funcionário incumbido ratione officii da guarda do livro ou documento" (HUNGRIA, N. Comentários ao código penal. Rio de Janeiro: Forense, 1959, p. 356).
} 


\section{CONSIDERAÇÓES FINAIS}

O presente estágio do fenômeno punitivo inspira a comparação, de um lado, entre a compreensão tradicional, segundo a qual o processo penal supóe a condenação a uma pena, cuja execução material se pospóe cronologicamente à declaraçáo da culpabilidade; e, de outro, uma compreensão contemporânea, estruturalmente comprometida com a desmaterialização parcial do ato mesmo de punir ${ }^{68}$.

Lecionava Carnelutti que a dúvida deriva da limitação própria da mente humana, para a qual a verdade "si frantuma nelle ragioni, come la luce dei colori" e só é apreendida "a piccole dosi" ${ }^{\text {'פ9 }}$. Ao magistrado brasileiro incumbe, portanto, evitar o "laxismo dogmático" no controle jurisdicional da pretensão acusatória, duvidando da narrativa articulada na denúncia, pela singela razáo de que o acusado se presume inocente e ostenta, por essa razão, o direito de ser bem acusado.

A essa conclusáo convergem, consoante demonstrado na primeira parte do artigo, os marcos normativos internacionais e nacionais que conformam o direito a ser bem acusado, com especial ênfase, de um lado, ao art. 8.2 do Pacto de São José da Costa Rica e ao art. 50, LIV, da Constituição Federal de 1988; de outro, à disciplina estabelecida pelos artigos 41, 395, 396, 396-A e 397, todos do Código de Processo Penal brasileiro.

Os casos expostos na segunda parte, de sua vez, ao mesmo tempo em que ilustram o superior potencial explicativo oferecido pela casuística forense, patenteiam que as consideraçôes meramente teóricas concernentes à relevância da previsão contida no art. 8-2 da $\mathrm{CADH}$ são insuficientes. Faz-se necessário afirmá-la nas hipóteses concretas de exercício abusivo da acusaçáo em contraste com o direito de ser bem acusado, de que sáo exemplos a imputaçáo de responsabilidade penalmente objetiva quanto ao crime de sonegaçáo de contribuição previdenciária (art. 337-A, CP) e quanto ao extravio, sonegação ou inutilização de livro ou documento (art. 314, CP), ambas subtratoras do pormenorizado conhecimento da acusação e dos meios adequados para a preparação da defesa.

\section{REFERÊNCIAS}

ALMEIDA, J. C. M. de. Processo penal. Ação e jurisdição. São Paulo: RT, 1975.

Princípios fundamentais do processo penal. São Paulo: RT, 1973.

ALMEIDA JÚNIOR, J. M. de. O processo criminal brazileiro. 3.ed. Rio de Janeiro: Baptista de Souza, 1920. Volumes 01 e 02.

AMBOS, K. Principios del proceso penal europeo. Análisis de la Convención Europea de Derechos Humanos. Traducido por Ana Beltrán e Guillermo Orce. Bogotá: Universidad Externado de Colombia, 2005. 2005, p. 282.

KERCHOVE, M. V. de. Quand dire, c'est punir. Essai sur le jugement pénal. Bruxelles: FUSL,

69 CARNELUTTI, F. Come si fa un processo. Torino: RAI, 1954, p. 66. 
AMODIO, E. Estetica della giustizia penale. Milano: Giuffrè, 2016.

AROCA, J. M. Principios del proceso penal. Una explicación basada en la razón. Buenos Aires: Astrea, 2016.

AUGUSTIN. La cité de Dieu. 3ème éd. Traduit du latin par L. Moreau. Paris: Jacques Lecoffre, 1851. Tome III.

BADARÓ, G. H. Juiz natural no processo penal. São Paulo: RT, 2014.

BRITO, A. C. de; FABRETTI, H. B.; LIMA, M. A. F. Processo penal brasileiro. 3.ed. São Paulo: Atlas, 2015.

CÂMARA LEAL, A. L. da. Comentários ao código de processo penal brasileiro. Rio de Janeiro: Freitas Bastos, 1942. Volume 01.

CAPOGRASSI, G. La Déclaration Universelle des Droits de l'Homme et sa signification. In: L'expérience juridique. Traduit de l'italien par Christophe Carraud. Paris: Conférence, 2016.

CARNELUTTI, F. Principi del processo penale. Napoli: Morano, 1960.

Las miserias del proceso penal. Traducido por Santiago Sentís Melendo. Buenos Aires: EJEA, 1959.

Come si fa un processo. Torino: RAI, 1954.

Mettere il pubblico ministero al suo posto. In: Rivista di diritto processuale. Padova: CEDAM, 1953. Volume VIII.

CARROLL, L. Alice's adventures in wonderland. Delaware: Prestwick House, 2005, p. 87.

CHOUKR, F. H. Código de processo penal. Comentários consolidados \& crítica jurisprudencial. 7.ed. Belo Horizonte: D’Plácido, 2017.Volume 02.

CUÉLLAR, J. B.; LYNETT, E. M. El proceso penal. Fundamentos constitucionales y teoría general. 6.ed Bogotá: Universidad Externado de Colombia, 2013.

DEMERCIAN, P. H.; MALULY, J. A. Curso de processo penal. 9.ed. Rio de Janeiro: Forense, 2014.

DEU, T. A. Sistemas procesales penales. La justicia penal en Europa y América. Madrid: Marcial Pons, 2012.

Estudios de justicia penal. Madrid: Marcial Pons, 2014.

ESPÍNOLA FILHO, E. Código de processo penal brasileiro anotado. 5.ed. Rio de Janeiro: Editora Rio, 1976. Volume 01. Tomo 01. 
CARVAlHO, L. G. G. C. Processo penal e constituição. 6.ed. São Paulo: Saraiva, 2014.

CASARA, R. Processo penal do espetáculo. In: PRADO, Geraldo; CHOUKR, A. C. F.; JAPIASSÚ, C. E. Processo penal e garantias. Estudos em homenagem ao professor Fauzi Hassan Choukr. 2.ed. Florianópolis: Empório do Direito, 2016.

COUTINHO, J. N. de M. Mettere il pubblico ministero al suo posto - ed anche il Giudice. In: CASARA, R.; LIMA, J. C. de (Coords.). Temas para uma perspectiva crítica do direito: homenagem ao professor Geraldo Prado. Rio de Janeiro: Lumen Júris, 2010.

DENZINGER, H. Compêndio dos símbolos, definiçốes e declaraçóes de fé e moral. 3.ed. São Paulo: Loyola, 2015.

DIAS, J. de F. Direito processual penal. Coimbra: Coimbra, 2004.

DIP, R.; JUNIOR, V. C. Crime e castigo. Campinas: Millennium, 2001.

FERRAJOLI, L. Derecho y razón. Teoría del garantismo penal. Traducido por Perfecto Andrés Ibáñez et al. 10.ed. Madrid: Trotta, 2016.

FIANDACA, G. Prima lezione di diritto penale. Bari: Laterza, 2017.

FISCHER, D. O que é garantismo (penal) integral? In: CALABRICH, B.; FISCHER, D; PELELLA, E. (Orgs.). Garantismo penal integral. 4.ed. Porto Alegre: Verbo Jurídico, 2017.

FOUCAULT, M. Surveiller et punir. Naissance de la prison. Paris: Gallimard, 1975.

GARAPON, A. Bien juger. Essai sur le rituel judiciaire. Paris: Odile Jacob, 2001.

Des crimes qu'on ne peut ni punir, ni pardonner. Pour une justice internationale. Paris: Odile Jacob, 2002.

GIACOMOLLI, N. J. O devido processo penal. 3.ed. São Paulo: Atlas, 2016.

GLOECKNER, R. J. Nulidades no processo penal. 3.ed. São Paulo: Saraiva, 2017.

GRECO FILHO, V. Manual de processo penal. 11.ed. São Paulo: Saraiva, 2017.

GUEDES, N. O princípio da congruência na ação civil pública de improbidade administrativa. In: MARQUES, M. C. (Coord.). Improbidade administrativa. Temas atuais e controvertidos. Rio de Janeiro: Forense, 2016.

HUNGRIA, N. Comentários ao código penal. 2.ed. Rio de Janeiro: Forense, 1959. Volume IX.

JACOB, R. Jugement des hommes et jugement de Dieu à l'aube du Moyen Âge. In: Le juge et le jugement dans les traditions juridiques européennes. Études d'histoire com- 
parée. Paris: LGDJ, 1996.

KHALED JR., S. Garantismo à la carte: integral, desnatado ou semi-desnatado? In: Justiça social e sistema penal. Rio de Janeiro: Lumen Juris, 2016.

KELSEN, H. Reine Rechtslehre. 2.Aufl. Wien: Österreichische Staatsdruckerei, 1992.

KERCHOVE, M. V. de. Quand dire, c'est punir. Essai sur le jugement pénal. Bruxelles: FUSL, 2005.

KOERING-JOULIN, R. A fase preparatória do processo penal: grandes linhas da jurisprudência europeia. In: DELMAS-MARTY, Mireille (org.). Processo penal e direitos do homem. Traduzido por Fernando de Freitas Franco. Barueri: Manole, 2004.

KOSTORIS, R. La Corte costituzionale e il caso Taricco, tra tutela dei 'controlimiti' e scontro tra paradigmi. In: BERNARDI, A.; CUPELLI, C. (orgs.). Il caso Taricco e il dialogo tra le Corti. L'ordinanza 24/2017 della Corte costituzionale. Napoli: Jovene, 2017.

LEAL, B. H. Processo penal de fronteira. Tópicos de experiência jurisdicional na Subseção de Tabatinga/AM. In: Revista do Tribunal Regional Federal da Primeira Regiáo. v. 30, pp. 17-37, 2018.

LIMA, R. B. de. Manual de processo penal. 6.ed. Salvador: Juspodivm, 2018.

LOPES JR., A. Direito processual penal. 14.ed. São Paulo: Saraiva, 2017.

LUGO, C. F. S. Los derechos del imputado em las audiências preliminares. La jurisprudencia nacional y de las cortes internacionales. In: El proceso penal acusatória colombiano. Bogotá: EJAM, 2006.

MANES, V. Il giudice nel labirinto. Profili delle intersezioni tra diritto penale e fonti sovranazionali. Roma: Diké Giuridica Editrice, 2012.

MANZINI, V. Trattato di diritto processuale penale. Torino: UTET, 1952. Volume 01.

MARQUES, J. F. Elementos de direito processual penal. 2.ed. Campinas: Millenium, 2000. Volume 02.

MONTESQUIEU, C. S., B. de la B. et de. L'ésprit des lois. Paris: Belin-Leprieur, 1845.

MOURA, M. T. R. de. Justa causa para ação penal. São Paulo: RT, 2001.

NORONHA, E. M. Curso de direito processual penal. 20.ed. São Paulo: Saraiva, 1990.

OST, F. Le temps du droit. Paris: Odile Jacob, 1999.

OTTO, H. Übungen im Strafrecht. 6.Aufl. Berlin: De Gruyter, 2005. 
ROXIN, C. Derecho procesal penal. Traducido por Gabriela Córdoba y Daniel Pastor. Buenos Aires: Del Puerto, 2000.

SALCUNI, G. L'interpretazione conforme al diritto europeo e la legittimazione democratica del giudice. In: MANNA, Adelmo (org.). Il problema dell'interpretazione nella giustizia penale. Pisa: PUP, 2016.

SANGUINÉ, O. Prisão cautelar. Medidas alternativas e direitos fundamentais. Rio de Janeiro: Forense, 2014. SANTORIELLO, C. L'abuso del processo. Pisa: PUP, 2018.

SIQUEIRA, G. Curso de processo criminal. 2.ed. São Paulo: Magalhães, 1937.

SPANGHER, G. Ragionamenti sul processo penale. Milano: Giuffrè, 2018.

La "vittima del processo" per ingiusta e illegale detenzione. In: SPANGHER, Giorgio. La vittima del processo penale. Torino: Giappichelli, 2017.

TORNAGHI, H. Instituiçóes de processo penal. 2.ed. São Paulo: Saraiva, 1977. Volume 02.

TRUCHE, P. Juger, être jugé. Le magistrat face aux autres et à lui-même. Paris: Fayard, 2001.

UBERTIS, G. Ancora sull'efficacia della giurisprudenza di Strasburgo. In: Argomenti di procedura penale IV. Milano: Giuffrè, 2016. 